\title{
ANALISIS PENGARUH KEPUTUSAN PEMBELIAN PADA KOSMETIK BERLABEL HALAL
}

\author{
Ratih Hesty Utami Puspitasari \\ Universitas PGRI Semarang
}

Email korespondensi: ratihhesty@upgris.ac.id

\begin{abstract}
This research aims to analyze the significant influence between halal labels, and price perceptions of Wardah's cosmetics purchasing decisions on Wardah counter consumers in the ADA Semarang supermarket. This study used descriptive quantitative methods. The population used is all consumers of the Wardah Swalayan ADA Semarang counter, with a total sample of 100 respondents taken using a purposive sampling technique. Data were analyzed through regression analysis using SPSS version 22. Results of the regression analysis in this study are Halal labels have a positive significant effect on purchasing decisions and price perception has a positive and significant effect on purchasing decisions.
\end{abstract}

Keywords: Halal labels; price perception; purchase decision

\section{A. PENDAHULUAN}

Industri kosmetik tumbuh pesat dewasa ini, dimana industri kosmetik menjadi salah satu industri di Indonesia yang berhasil menguasai pasar domestik. Maraknya Beauty Vloger juga meningkatkan animo masyarakat terhadap penggunaan kosmetik untuk melengkapi penampilan sehari-hari. Meningkatnya minat masyarakat terhadap penggunaan kosmetik juga meningkatkan minat produsen kosmetik untuk berlomba-lomba memberikan kosmetik yang sesuai dengan kebutuhan masyarakat. Dalam bukunya Kotler dan Keller (2008) menjelaskan bahwa perusahaan yang cerdas, akan memahami secara seksama proses pengambilan keputusan yang dilalui oleh pelanggan. Dengan demikian, perusahaan harus dapat mencerna pengalaman apa yang dimiliki pelanggan dalam belajar, memilih, menggunakan dan mendisposisikan produk.

Penelitian ini dilatarbelakangi oleh adanya kosmetik-kosmetik yang sudah mencantumkan label halal pada produknya. Produk kosmetik yang berlabel halal sudah tentu dapat memberikan jaminan kehalalan produk tersebut. Pembahasan mengenai bahan halal, tidak hanya berhubungan dengan produk makanan, tetapi juga kosmetik. Terdapat ketentuan dalam Islam bahwa jika akan Sholat, maka dipastikan tidak ada najis yang menempel pada tubuh. Oleh karena itu, aturan pemerintah dan fatwa Majelis Ulama Indonesia sangat dibutuhkan untuk mengambil jalan tengah dengan diterbitkan peraturan tentang jaminan produk halal. Dengan adanya peraturan ini, akan memberikan perlindungan dan kepastian 
hukum bagi masyarakat bahwa setiap produk kosmetik yang berlabel halal resmi dijamin halal menurut syariat Islam.

Hal lain yang diperhatikan dalam persaingan di industri kosmetik adalah persepsi mengenai harga. Persepsi harga memiliki peran penting dalam proses pengambilan keputusan pembelian. Seorang konsumen yang rasional akan memilih produk dengan mutu baik, harga terjangkau dan produk yang mudah didapat. Persepsi harga berkaitan dengan bagaimana informasi harga dipahami seluruhnya oleh konsumen dan memberikan makna yang dalam bagi konsumen itu sendiri. Berdasarkan latar belakang diatas, masalah dalam penelitian ini adalah bagaimana pengaruh label halal dan persepsi harga terhadap keputusan pembelian kosmetik.

\section{B. TELAAH PUSTAKA}

\section{Label Halal}

Label halal merupakan sejumlah keterangan pada kemasan produk. Secara umum, label yang baik minimal mencantumkan nama atau merek produk, bahan baku, bahan tambahan komposisi, informasi gizi, tanggal kadaluarsa, isi produk dan keterangan legalitas. Informasi didalam label sangat bermanfaat bagi konsumen. Dengan adanya label, konsumen dapat dengan mudah melakukan evaluasi terhadap produk yang akan dibelinya.

Terdapat beberapa macam label yang lebih spesifik dalam pengertiannya, misalnya yang pertama label produk, yaitu bagian dari pengemasan sebuah produk yang mengandung informasi mengenai produk atau penjualan produk. Macam label yang kedua yaitu label merek, yaitu nama merek yang diletakkan pada pengemasan produk. Ketiga yaitu label tingkat, yang mengidentifikasikan mutu produk, label ini bisa terdiri dari huruf, angka, atau metode lainnya untuk menunjukkan tingkat kualitas dari produk itu.

Label halal adalah pencantuman tulisan atau pernyataan halal pada kemasan produk untuk menunjukkan bahwa produk yang dimaksud berstatus sebagai produk halal. Produk halal adalah obat, produk pangan, kosmetika dan produk lain yang tidak mengandung unsur atau barang haram dalam proses pembuatannya. Produk halal juga tidak boleh mengandung unsur atau barang haram yang dilarang untuk dikonsumsi umat Islam baik yang menyangkut bahan baku, bahan tambahan, dan bahan pembantu lainnya. Bahan produksi yang diolah melalui proses rekayasa genetika dan iradiasi yang pengolahannya dilakukan sesuai dengan syariat Islam juga merupakan persyaratan dari label halal. Label halal diberikan kepada sebuah produk juga karena produk tersebut dan kandungan didalamnya memberikan lebih banyak manfaat daripada mudharatnya. 
Syarat kehalalan produk yang dipersyaratkan oleh LPPOM MUI antara lain yang pertama tidak mengandung DNA babi dan bahan-bahan yang berasal dari babi. Syarat yang kedua yaitu tidak mengandung bahan-bahan yang diharamkan seperti bahan yang berasal dari organ tubuh manusia, darah dan kotoran-kotoran. Ketiga yaitu semua bahan yang berasal dari hewan yang disembelih dengan syariat Islam. Syarat selanjutnya, yang harus diperhatikan adalah semua tempat penyimpanan, tempat penjualan, pengolahan dan transportasinya tidak boleh digunakan oleh daging babi.

\section{Persepsi Harga}

Harga adalah jumlah uang yang bisa ditambah dengan beberapa barang jika mungkin yang dibutuhkan untuk mendapatkan sejumlah kombinasi dari barang beserta pelayanannya. Dari pengertian tersebut, harga bukan hanya nominal uang, tetapi bisa jadi juga barang, waktu dan tenaga yang diperoleh untuk mendapatkan kombinasi dari barang yang diinginkan dan atau dibutuhkan. Berdasarkan strategi penetapan harga, manajer harus menetapkan dulu tujuan penetapannya. Tujuan ini berasal dari perusahaan itu sendiri yang selalu berusaha menetapkan atau menyajikan barang atau jasa secepat mungkin.

Menurut Kotler dan Keller (2008), terdapat faktor-faktor yang berpengaruh dalam penetapan harga antara lain biaya menjadi batas bawah, harga pesaing dan harga barang pengganti menjadi titik orientasi yang perlu dipertimbangkan perusahaan, penilaian pelanggan terhadap fitur-fitur produk yang unik dari penawaran perusahaan menjadi batas atas harga. Faktor-faktor tersebut harus dipahami oleh konsumen agar perusahaan tidak salah dalam proses penetapan harga. Karena konsumen sangat erat dengan proses mempersepsikan harga.

Persepsi harga berkaitan dengan bagaimana informasi harga dipahami seluruhnya oleh konsumen dan memberikan makna yang dalam bagi mereka. Berbagai informasi yang masuk di memori konsumen, dapat berpengaruh terhadap persepsi yang terbentuk. Apabila informasi yang diterima oleh konsumen tentang produk jelek, maka dengan tingkat harga tertentu, konsumen akan mempersepsikan produk kita mahal.

Asumsi mendasar dan yang umum telah berlaku di masyarakat adalah bahwa harga suatu produk sangat menentukan kualitasnya. Hal tersebut bermakna bahwa jika harga mahal maka dipersepsikan sebagai barang atau produk yang berkualitas. Menurut Djati dan Darmawan (2004), suatu tingkat harga yang tinggi menunjukkan kualitas yang tinggi atau status yang tinggi. Hasil penelitian tersebut menunjukkan kondisi seperti yang terjadi di masyarakat. 


\section{Keputusan Pembelian}

Keputusan pembelian menurut Kotler (2005) merupakan perilaku konsumen yang merujuk pada perilaku membeli konsumen akhir, individu dan rumah tangga yang membeli barang dan jasa untuk konsumsi pribadi. Sehingga dapat dipahami bahwa keputusan pembelian merupakan keputusan yang dilakukan oleh konsumen akhir yang dapat berupa individu dan rumah tangga dimana produk dan atau jasa yang dibelinya digunakan untuk konsumsi pribadi.

Para pemasar atau perusahaan harus melihat lebih jauh berbagai macam faktor yang mempengaruhi konsumen dalam melakukan keputusan pembelian. Dengan memahami pola keputusan pembelian, perusahaan dapat memenangkan hati pelanggan dan menjadikannya pelanggan setia terhadap perusahaan kita. Selain faktor yang utama dalam mempengaruhi keputusan pembelian konsumen, perusahaan harus dapat mengembangkan inovasi strategi pemasaran yang dapat menarik konsumen sehingga sampai pada keputusan pembelian.

Terdapat lima tahap dalam keputusan pembelian menurut Kotler dan Amstrong (2008) yaitu yang pertama pengenalan kebutuhan, yang kedua pencarian informasi, ketiga evaluasi alternatif dan keempat adalah keputusan pembelian. Perusahaan harus dapat memahami dan mengimplementasikan kebijakan pemasarannya agar dapat memenangkan perhatian konsumen di setiap tahapnya.

Berdasarkan telaah pustaka diatas, maka hipotesis dalam penelitian ini adalah :

$\mathrm{H}_{1}$ : Label halal berpengaruh positif terhadap keputusan pembelian, sehingga semakin terpercaya label halalnya, maka keputusan pembelian akan meningkat.

$\mathrm{H}_{2}$ : Persepsi harga berpengaruh positif terhadap keputusan pembelian, sehingga semakin baik persepsi harga, maka semakin tinggi keputusan pembelian.

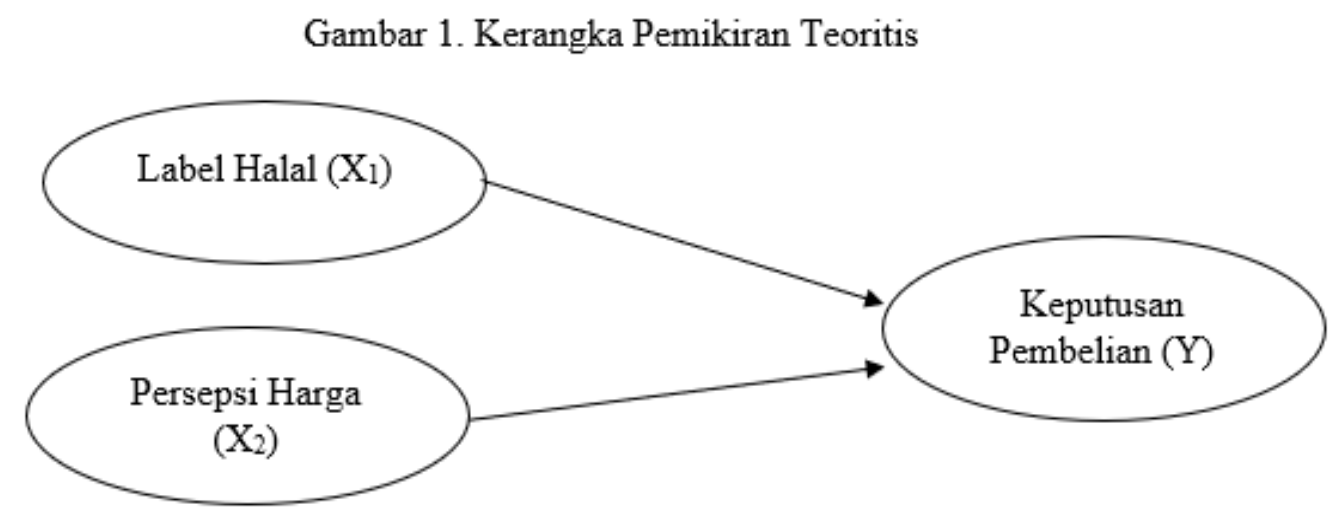

Sumber: Vivi Rahmawati (2014), Noreen Noor Abd Aziz dan Eta Wahab (2013), Yurina Nathasya Palinggi (2018), Windartatik (2013), I Dewa Putu Yosmara Adi Putra (2012), Ratna Dwi Kartika Sari (2012), Tintin Supriyansih (2010). 
Berdasarkan telaah pustaka yang disampaikan sebelumnya, maka model dalam penelitian dapat dilihat pada gambar 1 .

\section{METODOLOGI PENELITIAN}

Subjek penelitian atau responden dari penelitian ini adalah konsumen di counter wardah di swalayan ADA Semarang. Dari populasi konsumen Wardah di Counter Wardah Swalayan ADA, diambil sampel sebanyak 100 orang. Metode pengambilan sampel menggunakan non probability sampling yang menggunakan teknik purposive sampling. Teknik pengumpulan data dengan kuesioner yaitu cara pengumpulan data dengan menggunakan daftar isian atau pertanyaan yang sudah disiapkan dan disusun sedemikian rupa sehingga calon responden hanya tinggal mengisi atau menandainya dengan mudah dan cepat.

Dalam penelitian ini digunakan dua jenis variabel yaitu variabel independen atau variabel bebas dan variabel dependen atau variabel terikat. Variabel independen dalam penelitian ini adalah variabel label halal $\left(\mathrm{X}_{1}\right)$ dan persepsi harga $\left(\mathrm{X}_{2}\right)$, sedangkan variabel dependennya yaitu keputusan pembelian. Indikator yang digunakan adalah variabel label halal $\left(\mathrm{X}_{1}\right)$ adalah label halal dalam pertimbangan pembelian, kepercayaan konsumen, dan rasa aman konsumen. Untuk indikator yang digunakan dalam variabel persepsi harga $\left(\mathrm{X}_{2}\right)$ adalah harga yang ditetapkan, kesesuaian harga dan perbandingan harga dengan pesaing. Indikator yang digunakan dalam variabel keputusan pembelian antara lain konsumen membeli produk karena merasa cocok, konsumen mudah mengumpulkan informasi tentang produk dan konsumen membeli produk karena manfaat.

\section{HASIL DAN PEMBAHASAN}

Uji validitas menunjukkan sejauh mana instrumen pertanyaan dalam kuesioner yang digunakan dapat mengukur apa yang ingin diukur. Berdasarkan hasil uji validitas, diperoleh hasil seluruh pertanyaan dalam variabel dependen dan independen adalah valid karena memiliki koefisien lebih besar dari $\mathrm{r}$ tabel. Uji reliabilitas dalam penelitian ini disajikan dalam Tabel 1. Dimana didalamnya dapat dilihat bahwa semua variabel memiliki Cronbach's Alpa lebih dari 0,6. Maka dapat disimpulkan bahwa variabel label halal, persepsi harga dan keputusan pembelian telah diuji benar-benar benar- benar reliabel atau handal untuk digunakan dalam penelitian ini. 
Tabel 1. Hasil Pengujian Reliabilitas

\begin{tabular}{|c|c|c|c|}
\hline Variabel & Cranbach's Alpha & Standart & Keterangan \\
\hline Label halal & 0,727 & 0,60 & Reliabel \\
\hline Persepsi harga & 0,735 & 0,60 & Reliabel \\
\hline Keputusan Pembelian & 0,728 & 0,60 & Reliabel \\
\hline
\end{tabular}

Sumber : Output SPSS

\section{Analisis Regresi}

Analisis regresi linier berganda digunakan untuk mengetahui pengaruh variabel independen terhadap variabel dependen.

Tabel 2. Hasil Analisis Regresi

\begin{tabular}{|c|c|c|}
\hline Variabel & Koefisien Regresi & Probabilitas \\
\hline Constant & 2.127 & 0.004 \\
Persepsi Label Halal $\left(\mathrm{X}_{1}\right)$ & 0.516 & 0.000 \\
Persepsi Harga $\left(\mathrm{X}_{2}\right)$ & 0.150 & 0.010 \\
\hline
\end{tabular}

Sumber : Output SPSS

Berdasarkan hasil pengolahan data melalui SPSS, diperoleh persamaan regresi sebagai berikut :

$$
Y=2,127+0,516 X_{1}+0,77 X_{2}
$$

Nilai konstanta yaitu 2,127 artinya apabila label halal, persepsi harga nilainya sama dengan nol, maka keputusan pembelian kosmetik Wardah pada konsumen counter wardah di Swalayan ADA Semarang nilainya sebesar 2,127. Variabel label halal ( $\left.\mathrm{X}_{1}\right)$ memiliki koefisien sebesar 0,516. Hal ini menunjukkan bahwa setiap penambahan satu responden atas label halal pada kosmetik Wardah, akan dapat meningkatkan keputusan konsumen dalam membeli kosmetik Wardah sebesar 0,516 sedangkan variabel yang lain dianggap konstan. Koefisien regresi persepsi harga $\left(\mathrm{X}_{2}\right)$ sebesar 0,177 . Hal ini menunjukkan bahwa setiap penambahan satu tanggapan responden atas persepsi kualitas produk pada kosmetik Wardah maka akan dapat meningkatkan keputusan konsumen dalam membeli kosmetik Wardah sebesar 0,177 sedangkan variabel yang lain dianggap konstan. 


\section{Uji Hipotesis}

\section{Analisis Uji t}

Pengujian hipotesis pada penelitian ini dilakukan dengan menggunakan analisis Uji $\mathrm{t}$ yang dapat dilihat hasilnya pada Tabel 3 . Hasil analisis uji t juga dapat dilakukan dengan cara membandingkan hasil dari thitung dan $\mathrm{t}$ tabel sebagai berikut:

Tabel 3. Hasil Analisis Uji t

\begin{tabular}{|l|c|c|c|c|l|}
\hline \multirow{2}{*}{ Variabel } & \multicolumn{2}{|c|}{ thitung : tabel } & \multicolumn{2}{c|}{ Prob. Sig } & \multirow{2}{*}{ Keterangan } \\
\cline { 2 - 5 } & thitung & tabel & Sig & $\alpha=5 \%$ & \\
\hline Persepsi Label Halal $\left(\mathrm{X}_{1}\right)$ & 9,787 & 1,985 & 0,000 & 0,05 & Signifikan \\
Persepsi Harga $\left(\mathrm{X}_{2}\right)$ & 3,441 & 1,985 & 0,001 & 0,05 & Signifikan \\
\hline
\end{tabular}

Sumber : data diolah

Berdasarkan hasil analisis tersebut, maka dapat dijelaskan bahwa hasil uji t dari pengaruh label halal terhadap keputusan pembelian kosmetik Wardah menunjukkan bahwa nilai thitung sebesar 9,787 > tabel sebesar 1,985 serta memiliki nilai probabilitas sebesar 0,000 < tingkat signifikansi sebesar 0,05. Pada Tabel 3 juga diperoleh hasil regresi yang menunjukkan bahwa nilai koefisien dari variabel $\mathrm{X}_{1}$ adalah sebesar 0,516 yang bernilai positif sehingga hal ini berarti bahwa variabel label halal berpengaruh positif dan signifikan terhadap keputusan pembelian kosmetik Wardah sehingga hipotesis pertama diterima.

Selanjutnya untuk pengujian hipotesis ke dua yaitu hasil uji $\mathrm{t}$ antara variabel persepsi harga terhadap variabel keputusan pembelian kosmetik Wardah menunjukkan bahwa nilai $t_{\text {hitung }}$ sebesar 2,620 > tabel sebesar 1,985 serta memiliki nilai probabilitas sebesar 0,010 < tingkat signifikansi sebesar 0,05. Pada Tabel 3 juga diperoleh hasil regresi yang menunjukkan bahwa nilai koefisien dari variabel $\mathrm{X}_{2}$ adalah sebesar 0,15 yang bernilai positif sehingga hal ini berarti bahwa variabel persepsi harga berpengaruh positif dan signifikan terhadap keputusan pembelian kosmetik Wardah sehingga hipotesis kedua diterima.

\section{Analisis Uji F}

Hasil perhitungan uji F dapat dilihat pada Tabel 4. Berdasarkan hasil uji F dari Tabel 4, dapat dilihat bahwa $\mathrm{F}$ hitung sebesar 83,783 dan taraf signifikansi pada uji $\mathrm{F}$ di atas sebesar 0,000. Karena nilai signifikansi (sig) jauh lebih kecil dari 0,05 dan nilai $F$ hitung $>F$ tabel yaitu $83,783>2,70$ maka dapat dikatakan bahwa variabel label halal dan persepsi harga secara serempak atau bersama-sama berpengaruh secara signifikan terhadap keputusan pembelian kosmetik Wardah. 


\section{Tabel 4. Hasil Analisis Uji F}

ANOVA $^{\mathrm{a}}$

\begin{tabular}{|l|l|r|r|r|r|r|}
\hline \multicolumn{2}{|c|}{ Model } & \multicolumn{1}{c|}{$\begin{array}{c}\text { Sum of } \\
\text { Squares }\end{array}$} & df & \multicolumn{1}{c|}{$\begin{array}{c}\text { Mean } \\
\text { Square }\end{array}$} & F & Sig. \\
\hline 1 & Regression & 83.788 & 3 & 27.929 & 83.783 & $.000^{\mathrm{a}}$ \\
& Residual & 32.002 & 96 & .333 & & \\
& Total & 115.790 & 99 & & & \\
\hline
\end{tabular}

Sumber : Output SPSS

\section{Koefisien Determinasi (Adjusted R Square)}

Koefisien determinasi (Adjusted R Square) digunakan untuk menghitung seberapa besar perubahan variabel independen yang mampu menjelaskan perubahan pada variabel dependen. Nilai koefisien determinasi (Adjusted $R$ Square) pada penelitian ini dapat dilihat pada Tabel 5.

\section{Tabel 5. Koefisien Determinasi}

Model Summary ${ }^{b}$

\begin{tabular}{|c|c|c|c|c|}
\hline Model & R & R Square & $\begin{array}{c}\text { Adjusted } \\
\text { R Square }\end{array}$ & $\begin{array}{c}\text { Std. Error of } \\
\text { The Estimate }\end{array}$ \\
\hline 1 & $.851^{\mathrm{a}}$ & .724 & .715 & .577 \\
\hline
\end{tabular}

Sumber : Output SPSS

Data yang didapatkan dari hasil SPSS, diperoleh hasil nilai Adjusted $R$ Square sebesar 0,715. Hal ini menunjukkan jika seluruh variabel independen dalam penelitian ini yaitu label halal $\left(\mathrm{X}_{1}\right)$ dan persepsi harga $\left(\mathrm{X}_{2}\right)$ mempunyai pengaruh secara bersama-sama sebesar $71,5 \%$ terhadap variabel dependen yaitu keputusan pembelian, sedangkan sisanya yaitu 28,5\% dipengaruhi oleh variabel-variabel lainnya yang tidak diteliti dalam penelitian ini.

Hasil pengujian hipotesis pertama dan kedua dengan menggunakan program aplikasi SPSS menunjukkan hasil bahwa Ha diterima dan Ho ditolak artinya hipotesis satu dan dua diterima dengan nilai koefisien regresi positif. Hasil tersebut menggambarkan bahwa pencantuman label halal merupakan hal yang paling dominan dipertimbangkan dalam proses keputusan pembelian konsumen, oleh sebab itu perusahaan harus dapat menjaga kehalalan kosmetik tersebut dengan berhati - hati. Termasuk juga mengenai pemilihan bahan pembuatan kosmetik dengan tetap menggunakan bahan - bahan alami tanpa bahan kimia yang berbahaya dan mengandung unsur haram. 
Produsen tetap harus melakukan promosi secara gencar dengan mengedepankan keunggulan label halal yang telah diciptakan oleh Wardah sehingga tetap bersaing di pasaran. Dengan adanya Wardah sebagai salah satu kosmetik halal, akan menjadikan ketatnya persaingan dengan munculnya merek kosmetik lain yang mengusung kehalalan produknya. Produsen merek Wardah juga selalu dituntut untuk meningkatkan kualitas prosuknya agar semakin dapat membuat konsumen percaya dengan kualitasnya dan dapat melakukan berbagai inovasi sesuai dengan kebutuhan konsumen dan tentu saja dengan harga yang tetap terjangkau.

\section{E. KESIMPULAN}

Berdasarkan hasil uji t dapat disimpulkan bahwa secara parsial variabel label halal $\left(\mathrm{X}_{1}\right)$ dan persepsi harga $\left(\mathrm{X}_{2}\right)$ berpengaruh positif signifikan terhadap keputusan pembelian produk Wardah pada konsumen counter Wardah di Swalayan ADA Semarang. Maka, hipotesis pertama yang mengatakan bahwa diduga ada pengaruh positif antara persepsi label halal dan persepsi harga terhadap keputusan pembelian kosmetik Wardah pada konsumen counter Wardah di Swalayan ADA Semarang secara parsial dapat diterima. Begitu pula untuk hipotesis dua juga diterima karena berdasarkan hasil uji t dapat diketahui bahwa persepsi harga berpengaruh positif terhadap keputusan pembelian.

Berdasarkan hasil uji F dapat disimpulkan bahwa secara berganda variabel persepsi label halal $\left(\mathrm{X}_{1}\right)$ dan persepsi harga $\left(\mathrm{X}_{2}\right)$ berpengaruh positif dan signifikan terhadap keputusan pembelian produk Wardah pada konsumen counter Wardah di Swalayan ADA Semarang. Artinya, hipotesis yang mengatakan bahwa diduga ada pengaruh positif antara persepsi label halal dan persepsi harga terhadap keputusan pembelian kosmetik Wardah pada konsumen counter Wardah di Swalayan ADA Semarang secara simultan juga dapat diterima.

Penelitian yang akan datang mengenai produk halal dapat meneliti dengan objek yang sama namun dapat diperluas scope (wilayah penelitiannya) serta dapat menambah variabel independennya agar dapat mengetahui variabel- variabel lain yang berpengaruh terhadap keputusan pembelian. Pada penelitian berikutnya diharapkan dapat mengetahui lebih jauh faktor - faktor pendukung yang dapat digunakan untuk mempengaruhi konsumen dalam melakukan keputusan pembelian terutama produk halal. 


\section{DAFTAR PUSTAKA}

Abd Aziz, Noreen Noor and Wahab, Eta. (2013). "Understanding of Halal Cosmetics Products : TPB Model”. Jurnal. University Tun Hussein Onn Malaysia.

Darmadi Durianto, Sugiarto, dan Tony S. (2004). Strategi Menaklukkan Pasar Melalui Riset Ekuitas dan Perilaku Merek. Jakarta: PT. Gramedia Pustaka Utama.

I Dewa Putu Yosmara Adi Putra. (2012). Analisis Kesadaran Merek, Persepsi Kualitas, Asosiasi Merek, dan Loyalitas Merek yang Mempengaruhi Ekuitas Merek Produk Handphone Nokia. Skripsi. Universitas Diponegoro Semarang.

Kotler, Philip dan Keller, L. Kevin. (2008). Manajemen Pemasaran Jilid II (edisi ke- 12). Jakarta : Indeks Media. .(2005). Manajemen Pemasaran Jilid I (edisi ke-11). Jakarta : PT Indeks Media.

Ratna Dwi Kartika Sari. (2012). Analisis Pengaruh Kualitas Produk, Persepsi Harga, Dan Word Of Mouth Communication Terhadap Keputusan Pembelian Mebel Pada CV. Mega Jaya Mebel Semarang. Skripsi. Universitas Diponegoro Semarang.

Tatik Suryani. (2008). Perilaku Konsumen : Implikasi pada Strategi Pemasaran. Edisi Pertama. Cetakan Pertama. Jakarta : Graha Ilmu.

Tintin Supriyansih. (2010). Faktor Faktor Atribut Produk yang Mempengaruhi Keputusan Pembelian Kosmetik Wardah di Toserba Luwes Lojiwetan Surakarta. Skripsi. Universitas Sebelas Maret Surakarta.

Vivi Rahmawati. (2018). Pengaruh Atribut Produk dan Label Halal Sebagai Variabel Moderating Terhadap Keputusan Pembelian Produk Kosmetik Wardah di Kota Semarang. Jurnal. Universitas Dian Nuswantoro.

Windartatik. (2013). Pengaruh Label Halal MUI dan Brand Image Terhadap Minat Membeli Produk Kosmetik Wardah. Skripsi. Institut Agama Islam Negeri Walisongo Semarang.

Yurina Nathasya Palinggi. (2018). Pengaruh Strategi Marketing Mix Terhadap Keputusan Pembelian Produk Wardah Pada PT Paragon Technology and Innovation di Makassar. Skripsi. Universitas Hassanudin Makasar. 